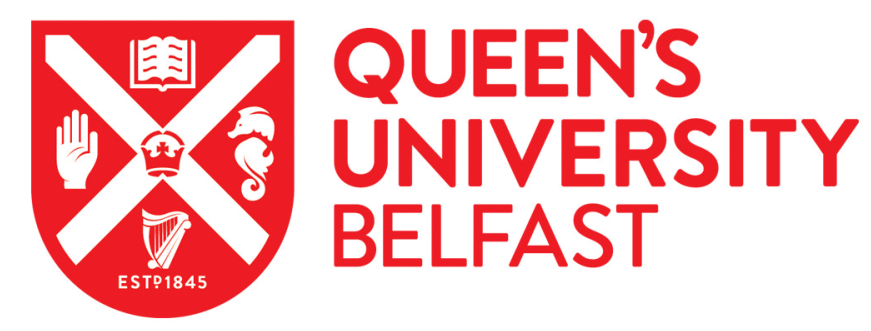

\title{
In situ selective measurement based on Diffusive Gradients in Thin- Films technique with mercapto-functionalized mesoporous silica for high-resolution imaging of Sblll in soil
}

Fang, W., Shi, X., Yang, D., Hu, X., Williams, P. N., Shi, B., Liu, Z., \& Luo , J. (2020). In situ selective measurement based on Diffusive Gradients in Thin-Films technique with mercapto-functionalized mesoporous silica for high-resolution imaging of Sblll in soil. Analytical Chemistry, 92(5), 3581.

https://doi.org/10.1021/acs.analchem.9b04225

Published in:

Analytical Chemistry

Document Version:

Peer reviewed version

Queen's University Belfast - Research Portal:

Link to publication record in Queen's University Belfast Research Portal

\footnotetext{
Publisher rights

(c) 2020 American Chemical Society. This work is made available online in accordance with the publisher's policies. Please refer to any applicable terms of use of the publisher.
}

\section{General rights}

Copyright for the publications made accessible via the Queen's University Belfast Research Portal is retained by the author(s) and / or other copyright owners and it is a condition of accessing these publications that users recognise and abide by the legal requirements associated with these rights.

Take down policy

The Research Portal is Queen's institutional repository that provides access to Queen's research output. Every effort has been made to ensure that content in the Research Portal does not infringe any person's rights, or applicable UK laws. If you discover content in the Research Portal that you believe breaches copyright or violates any law, please contact openaccess@qub.ac.uk. 


\section{Article}

\section{In situ selective measurement based on Diffusive Gradients in Thin-Films technique with mercapto-functionalized mesoporous silica for high-resolution imaging of Sblll in soil}

Wen Fang, Xinyao Shi, Danxing Yang, Xuan Hu, Paul Nicholas Williams, Bingqing Shi, Zhaodong Liu, and Jun Luo

Anal. Chem., Just Accepted Manuscript • DOI: 10.1021/acs.analchem.9b04225 • Publication Date (Web): 09 Jan 2020

Downloaded from pubs.acs.org on January 14, 2020

\section{Just Accepted}

"Just Accepted" manuscripts have been peer-reviewed and accepted for publication. They are posted online prior to technical editing, formatting for publication and author proofing. The American Chemical Society provides "Just Accepted" as a service to the research community to expedite the dissemination of scientific material as soon as possible after acceptance. "Just Accepted" manuscripts appear in full in PDF format accompanied by an HTML abstract. "Just Accepted" manuscripts have been fully peer reviewed, but should not be considered the official version of record. They are citable by the Digital Object Identifier (DOI®). "Just Accepted" is an optional service offered to authors. Therefore, the "Just Accepted" Web site may not include all articles that will be published in the journal. After a manuscript is technically edited and formatted, it will be removed from the "Just Accepted" Web site and published as an ASAP article. Note that technical editing may introduce minor changes to the manuscript text and/or graphics which could affect content, and all legal disclaimers and ethical guidelines that apply to the journal pertain. ACS cannot be held responsible for errors or consequences arising from the use of information contained in these "Just Accepted" manuscripts. 


\title{
In situ selective measurement based on Diffusive Gradients in Thin-Films technique with mercapto-functionalized mesoporous silica for high-resolution imaging of $\mathrm{Sb}^{\mathrm{III}}$ in soil
}

\author{
Wen Fang, ${ }^{\dagger}+$ Xinyao Shi,${ }^{\dagger} *$ Danxing Yang, ${ }^{\dagger}$ Xuan Hu, ${ }^{\dagger}$ Paul N. Williams ${ }^{\S}$, Bingqing \\ Shi, ${ }^{\dagger}$ Zhaodong Liu, ${ }^{\dagger}$ Jun $\mathrm{Luo}^{* \dagger}$
}

\begin{abstract}
†State Key Laboratory of Pollution Control and Resource Reuse, School of the Environment, Nanjing University, Jiangsu 210023, China
\end{abstract}

§Institute for Global Food Security, School of Biological Sciences, Queen’s University Belfast, Belfast BT9 7BL, United Kingdom

* Corresponding authors, 0086-25-89680623, esluojun@nju.edu.cn

$¥$ W. Fang and X. Shi contributed equally to this work and should be considered co-first authors. 


\section{ABSTRACT}

In situ monitoring of $\mathrm{Sb}$ speciation improves the understanding of $\mathrm{Sb}$ biogeochemistry and toxicity in ecosystems. Precise measurement of Sb is a challenge due to its instability of oxidation and ultra-trace concentration. The development of simple and reliable methods specific to $\mathrm{Sb}^{\mathrm{III}}$ measurement is not only appealing but essential for implementing regulations. Here, we present an in situ speciation analysis method for $\mathrm{Sb}^{\mathrm{III}}$, using the diffusive gradients in thin films (DGT) technique, combined with mercapto functionalized SBA-15 mesoporous silica nanoparticles (MSBA). Laboratory performance tests confirmed MSBA-DGT uptake was independent of $\mathrm{pH}$ (4-9) and ionic strength $\left(0.1-200 \mathrm{mmol} \mathrm{L}^{-1}\right)$. DGT devices equipped with MSBAbased binding gels showed a theoretically linear accumulation of $\mathrm{Sb}^{\mathrm{III}}$ and exhibited high capacity for $\mathrm{Sb}^{\mathrm{III}}$ at $65 \mu \mathrm{g}$ per gel disc, with negligible accumulation of $\mathrm{Sb}^{\mathrm{V}}$ over a $72 \mathrm{~h}$ deployment. Compared with commercial 3-Mercaptopropyl functionalized silica (MFS), the nano-sized MSBA facilitate its even distribution in the binding gels. Furthermore, the good selectivity and high homogeneity of the MSBA gel enabled it to be applied in a rice rhizosphere in conjunction with $\mathrm{AgI}$ gel to investigate the effects of sulfur application on the $\mathrm{Sb}^{\mathrm{III}}$ solubility. In summary, the newly developed MSBADGT provides a selective measurement of $\mathrm{Sb}^{\mathrm{III}}$, showing potential for environmental monitoring and further application in understanding biogeochemical process of $\mathrm{Sb}$. 


\section{INTRODUCTION}

Antimony ( $\mathrm{Sb})$ is a toxic element and considered to be one of the key priority pollutants of interest in the United States, European Union and China. ${ }^{1-4}$ Elevated concentrations of $\mathrm{Sb}$ have been reported in soils and waters collected from the regions of mining, smelters, and shooting ranges. ${ }^{5-7}$ China has the most abundant $\mathrm{Sb}$ resources in the world, with approximately $84 \%$ of the world's reserves. ${ }^{2}$ Large quantities of $\mathrm{Sb}$ released from mining and smelting processes cause serious Sb contamination and hence pose a significant human health and environmental risk. ${ }^{3,8}$

The toxicity of $\mathrm{Sb}$ depends strongly on its oxidation states. ${ }^{9} \mathrm{Sb}^{\mathrm{III}}$ and $\mathrm{Sb}^{\mathrm{V}}$ are the predominant species of $\mathrm{Sb}$ in the environment and they can be absorbed by plants from soil, causing adverse health effects to humans via the food chain. ${ }^{10} \mathrm{Sb}^{\mathrm{III}}$ has ten times higher acute toxicity than $\mathrm{Sb}^{\mathrm{V}}$ and poses a greater risk to organisms. ${ }^{11}$ Consequently, an effective method to evaluate $\mathrm{Sb}$ speciation is necessary for understanding $\mathrm{Sb}$ distribution and toxicity in the environment. Usually, $\mathrm{Sb}$ speciation analysis is conducted by grab sample collection of waters followed by preconcentration/separation using specific adsorbents, ${ }^{12}$ extraction, ${ }^{13-15}$ ion exchange, ${ }^{16}$ electrochemical methods, ${ }^{17}$ and hydride generation methods. ${ }^{18}$ However, the sample treatment is often timeconsuming and subject to problems related to the instability of Sb species caused by properties of the sampled media, such as $\mathrm{pH}$, redox potential, organic matter, and biotic fauna. ${ }^{19}$ During the sample storage, physicochemical properties are prone to change, thereby leading to Sb speciation transformation. ${ }^{20}$ Moreover, active sampling captures 
only an instantaneous concentration, which can result in an inaccurate estimation of $\mathrm{Sb}$ concentration over time.

The diffusive gradients in thin-films (DGT) technique has been comprehensively validated for in situ measurement of inorganic species in waters ${ }^{21,22}$ and metal fluxes in soils and sediments. ${ }^{23-25}$ Within DGT devices, the targeted analyte diffuses through an inert filter membrane and hydrogel stack and is immobilized in a binding layer which has high affinity for the analyte of interest. ${ }^{26}$ The key step of the DGT technique, where the targeted species are selectively accumulated from solution, is performed in situ. This makes DGT an ideal tool for in situ speciation analysis. Recently, the application of selective binding phase has made it feasible to use DGT for speciation analysis of arsenic, selenium, and chromium. ${ }^{27-31}$ 3-Mercaptopropyl functionalized silica (MFS) based DGT has been validated for the selective measurement of labile $\mathrm{Sb}^{\mathrm{III}}$ in waters and sediments due to the strong affinity between $\mathrm{Sb}^{\mathrm{III}}$ and thiol groups. ${ }^{30,31}$ However, the relatively large bead size of MFS resin (200-400 mesh) causes heterogeneous distribution of the resin within the binding gel that limits its application in high resolution mapping of $\mathrm{Sb}^{\mathrm{III}}$ in plant rhizosphere or sediments. High resolution (HR) DGT techniques has been demonstrated to be a promising tool for visualization of element bioavailability in the rhizosphere zones with sub-mm scale. ${ }^{32,33}$ It thus requires the binding phase not only to be effective in adsorption of targeted elements, but also to be homogenous with evenly distributed binding materials.

$\mathrm{Sb}$ uptake by rice is a major health concern to residents in $\mathrm{Sb}$ mining area 4 
(Xikuangshan, China) since rice consumption contributed approximately $33 \%$ to their total $\mathrm{Sb}$ dietary intake. ${ }^{10}$ This further underscores the importance of investigating the biogeochemical behavior of $\mathrm{Sb}$ in the rice rhizosphere where $\mathrm{Sb}$ transfers from soils to plants. The biogeochemical cycling and speciation transformation of $\mathrm{Sb}$ are often coupled with sulfur and sulfate reduction process. ${ }^{34}$ The sulfide is usually assumed to facilitate $\mathrm{Sb}$ immobilization through $\mathrm{Sb}$ sulfide precipitation. ${ }^{35}$ On the other hand, some studies have revealed sulfate might favor $\mathrm{Sb}$ mobilization through sulfate-reducing bacteria. ${ }^{36}$ The rice rhizosphere zone is reported to induce steep changes in localized redox conditions, ${ }^{33}$ thereby leading to complex sulfur related oxidation and reaction process, while the effect of these processes on $\mathrm{Sb}$ mobilization in the rhizosphere remains incomplete. Furthermore, both sulfur and $\mathrm{Sb}$ speciation are sensitive to redox change, resulting in their chemical reactions being highly susceptible to disturbance. This necessitates the development and application of in situ and high resolution sampling methods to assess the coupled behavior of sulfur and $\mathrm{Sb}$ in the rhizosphere.

Here, we prepared a DGT binding layer using mercapto-functionalized SBA-15 nanoparticles (MSBA) and investigated performance characteristics of this DGT method for selective measurement of $\mathrm{Sb}^{\mathrm{III}}$ in the laboratory. The binding gel made from the MSBA nanoparticles enabled its application in the rice rhizosphere for two dimensional (2D) HR visualization of $\mathrm{Sb}^{\mathrm{III}}$ bioavailability. Responses of $\mathrm{Sb}^{\mathrm{III}}$ bioavailability to sulfate application in the rice rhizosphere were investigated through spatial 2D mapping of $\mathrm{Sb}^{\mathrm{III}}$ and $\mathrm{S}^{2-}$ using this DGT binding layer coupled with AgI 
binding layer. ${ }^{37}$

\section{EXPERIMENTAL SECTION}

Chemical and Reagents. To prepare the new binding resin (MSBA) for selective measurement of $\mathrm{Sb}^{\text {III }}, \mathrm{P} 123$ (poly(ethylene oxide) ${ }_{20}$-poly(propylene oxide) ${ }_{70^{-}}$ poly(ethylene oxide) 20 and 3-Mercaptopropyl-trimethoxysilane (MPTMS, $\mathrm{C}_{6} \mathrm{H}_{16} \mathrm{O}_{3} \mathrm{SSi}$ ) were purchased from Sigma-Aldrich. Tetraethyl orthosilicate (TEOS, 98\%) was purchased from Aladdin. 3-Mercaptopropyl-functionalized silica gel (SigmaAl-drich, St. Louis, MO), 200-400 mesh, was used for preparation of MFS binding gel. Hydrochloric acid and nitric acid were obtained from Sinopharm Chemical Reagent Co., Ltd., Shanghai, China. Chemicals used in this study were of analytical reagent grade or equivalent.

Stock solutions of antimonite $\left(\mathrm{Sb}^{\mathrm{III}}\right)$ and antimonate $\left(\mathrm{Sb}^{\mathrm{V}}\right)$ at $1000 \mathrm{mg} \mathrm{L}^{-1}$ were prepared from $\mathrm{C}_{8} \mathrm{H}_{4} \mathrm{~K}_{2} \mathrm{O}_{12} \mathrm{Sb}_{2} \cdot 3 \mathrm{H}_{2} \mathrm{O}$ (Sigma-Aldrich, 99\%) and $\mathrm{KSb}(\mathrm{OH})_{6}($ Fluka, 99\%) with Milli-Q water $(18.2 \mathrm{M} \Omega \cdot \mathrm{cm}$, Millipore, USA). The stock solutions were stored in the dark at $4{ }^{\circ} \mathrm{C}$ for future use.

Chemical Analysis. An inductively coupled plasma mass spectrometry (ICP-MS, NexION 300X, PerkinElmer) was employed for Sb measurement. Indium (m/z 115) was used as an internal standard throughout the analysis to ensure accuracy and precision. The SLRS-6 river water reference material (National Research Council Canada) with a certified value of Sb was measured during ICP-MS analysis to confirm the robustness of the analytical procedure. All standard solutions were diluted from the 
stock solution with $0.1 \mathrm{M} \mathrm{HNO}_{3}$. The average recovery was $97.6 \pm 5.7 \%(\mathrm{n}=10)$.

$\mathrm{Sb}$ speciation was measured by high performance liquid chromatography (HPLC, PerkinElmer, USA) coupled with ICP-MS. A PRP-X100 anion-exchange column (10 $\mu \mathrm{m}$, Hamilton, UK) was used to separate the Sb species. The mobile phase consisted of $10 \mathrm{mM}$ EDTA and $2 \mathrm{mM}$ potassium hydrogen phthalate, with $\mathrm{pH}$ adjustment to 4.5 using ammonium hydroxide. ${ }^{38}$ Sample injection volume was $50 \mu \mathrm{L}$ and flow rate 1.2 $\mathrm{mL} \min ^{-1}$. Details of instrumental conditions are listed in the Supporting Information (Table S1).

DGT Procedures. A typical DGT device is comprised of a protective hydrophilic polyethersulfone membrane of $0.45 \mu \mathrm{m}$ pore size and $0.14 \mathrm{~mm}$ thickness (Pall, USA), a polyacrylamide diffusive gel layer, and a binding gel layer, and a set of plastic molding (DGT Research Ltd., UK) having a base and a cap with a circular exposure window of $2.51 \mathrm{~cm}^{2}$. All moldings were immersed in $10 \%(\mathrm{v} / \mathrm{v})$ nitric acid for at least $24 \mathrm{~h}$ and rinsed several times with Milli-Q water before use.

Agarose-cross-linked (DGT Research Ltd., UK) polyacrylamide diffusive gels were prepared according to Zhang and Davison. ${ }^{39}$ DGT binding layers containing 3mercaptopropyl-functionalized silica (MFS) 27, 31 were provided by DGT Research Limited Corporation (www.dgtresearch.com). To prepare the novel binding gel, synthesized mercapto-functionalized SBA-15 mesoporous silica (MSBA) was used as the sorbent according to Aguado et al. ${ }^{40}$ with some modification (see SI for details). The binding gel was made by mixing $0.2 \mathrm{~g}$ of MSBA resin with $3 \mathrm{~mL}$ of gel solution, 
which contains $37.5 \%$ acrylamide (w/v), 47.5\% Milli-Q water (w/v) and 15\% agarosederived cross-linker $(\mathrm{w} / \mathrm{v})$. The mixture was sonicated in an ice bath for $10 \mathrm{~min}$ to ensure the resin fully dispersed, followed by the addition of $24 \mu \mathrm{L}$ of freshly prepared $10 \%$ ammonium persulphate solution (AnalaR, BDH) and $6 \mu \mathrm{L}$ of $N, N, N^{\prime} N^{\prime}-$ tetramethyl ethylenediamine (TEMED, 99\%, Merck, Germany). Normal (0.25 mm thickness) and ultrathin (0.06 mm thickness) MSBA gels were cast following standard procedures for preparation of binding gels with normal thickness and ultrathin thickness ${ }^{29}$ and stored in $0.01 \mathrm{~mol} \mathrm{~L}^{-1} \mathrm{NaNO}_{3}$ and $0.01 \mathrm{~mol} \mathrm{~L}^{-1} \mathrm{NaCl}$ solution, respectively, prior to use. $\mathrm{NaCl}$ solution was used for ultrathin gel storage to avoid any potential $\mathrm{NO}_{3}{ }^{-}$catalyzed oxidation reactions during gel deployment in the rhizosphere.

Binding Kinetics and Elution Efficiencies of Binding Gels. The uptake kinetics of Sb by the binding gel containing MSBA resins was investigated by exposing a cut MSBA gel disc (2.51 cm diameter) to a $10 \mathrm{~mL}$ of solution containing $50 \mu \mathrm{g} \mathrm{L}^{-1} \mathrm{Sb}^{\mathrm{III}}$ or $\mathrm{Sb}^{\mathrm{V}}$, with a matrix of $0.01 \mathrm{~mol} \mathrm{~L}^{-1} \mathrm{NaNO}_{3}$, for various times from 3 min to $24 \mathrm{~h}$. The concentrations of $\mathrm{Sb}$ in the solutions before and after gel immersion were measured. The MSBA gel discs loaded with different amounts of $\mathrm{Sb}^{\mathrm{III}}$ were eluted in $1 \mathrm{~mL}$ of $1 \mathrm{M}$ $\mathrm{HNO}_{3}, 1 \mathrm{~mL}$ of $1 \mathrm{M} \mathrm{HNO}_{3}+1 \% \mathrm{KIO}_{3}(\mathrm{~m} / \mathrm{v})$, or $3 \mathrm{~mL}$ of $1 \mathrm{M} \mathrm{HNO}_{3}+1 \% \mathrm{KIO}_{3}(\mathrm{~m} / \mathrm{v})$ for at least $24 \mathrm{~h}$ to investigate the accurate elution efficiency. All samples prepared were in triplicate. The concentrations of eluents were measured using ICP-MS, after having been diluted by at least 20 -fold to limit the signal suppression due to the presence of $\mathrm{KIO}_{3}$. The mass, $M$, of $\mathrm{Sb}$ in the binding gel, was calculated by eq $1^{39}$ 


$$
M=\frac{C_{\mathrm{e}}\left(V_{\mathrm{g}}+V_{\mathrm{e}}\right)}{f_{\mathrm{e}}}
$$

Where $C_{\mathrm{e}}$ is the concentration of $\mathrm{Sb}$ in the elution samples, $V_{\mathrm{g}}$ is the volume $(0.16 \mathrm{~mL})$ of the binding gel, $V_{\mathrm{e}}$ is the volume of elution solution, and $f_{\mathrm{e}}$ is the elution efficiency.

DGT Performances in the Laboratory. Effects of $p H$ and ionic strength. The effect of $\mathrm{pH}$ on the performance of the new DGT devices containing the MSBA binding gel (MSBA-DGT) was tested by deploying triplicate MSBA-DGT devices containing $0.8 \mathrm{~mm}$ thick diffusive gels in $2 \mathrm{~L}$ of $50 \mu \mathrm{g} \mathrm{L}^{-1} \mathrm{Sb}^{\mathrm{III}}$ and $0.01 \mathrm{~mol} \mathrm{~L}^{-1} \mathrm{NaNO}_{3}$ wellstirred solutions at different $\mathrm{pH}$, ranging from 3.2 to 9.1 , for $4 \mathrm{~h}$. Regarding the solutions with high $\mathrm{pH}$ of $8-9$, before the $\mathrm{Sb}^{\mathrm{III}}$ stock solution was added, $0.01 \mathrm{~mol} \mathrm{~L}^{-1} \mathrm{NaNO}_{3}$ solutions were stabilized for ca. 3 days by adjusting the $\mathrm{pH}$ using $1 \mathrm{M} \mathrm{NaOH}$ every 12 h. Similarly, to estimate the effect of ionic strength, MSBA-DGT devices containing $0.8 \mathrm{~mm}$ thick diffusive gels were immersed in $2 \mathrm{~L}$ of well-stirred solutions containing $50 \mu \mathrm{g} \mathrm{L}^{-1} \mathrm{Sb}^{\mathrm{III}}$ and different concentrations of $\mathrm{NaNO}_{3}$ ranging from $0.1-200 \mathrm{mmol} \mathrm{L}^{-1}$ at $\mathrm{pH} 6.0 \pm 0.5$, for $4 \mathrm{~h}$. The $\mathrm{pH}$ values were adjusted with $1 \mathrm{~mol} \mathrm{~L}^{-1} \mathrm{HNO}_{3}$ or $1 \mathrm{~mol}$ $\mathrm{L}^{-1} \mathrm{NaOH}$. The diffusion coefficient of $\mathrm{Sb}^{\mathrm{III}}$ adopted in this study was $9.42 \times 10^{-6} \mathrm{~cm}^{2}$ $\mathrm{s}^{-1}$ reported by Bennett et al. ${ }^{31}$

Selective measurement of $S b^{I I I}$. To monitor selective measurement of $\mathrm{Sb}^{\mathrm{III}}$ by MSBA-DGT devices, the MSBA-DGT devices containing $0.8 \mathrm{~mm}$ thick diffusive gels were exposed in $6 \mathrm{~L}$ of well-stirred solutions containing $50 \mu \mathrm{g} \mathrm{L}^{-1} \mathrm{Sb}^{\mathrm{III}}$ or $\mathrm{Sb}^{\mathrm{V}}$ and 0.01 mol L ${ }^{-1} \mathrm{NaNO}_{3}$. Triplicate DGT devices were removed after 4, 8, 12, 24, 48, and $72 \mathrm{~h}$. Competition Effect between $S b^{I I I}$ and $S b^{V}$. To further examine the selective 
performance of MSBA-DGT for $\mathrm{Sb}^{\mathrm{III}}$, triplicate MSBA-DGT devices containing 0.8 $\mathrm{mm}$ thick diffusive gels were deployed for $4 \mathrm{~h}$ in $2 \mathrm{~L}$ of well-stirred solutions containing $0.01 \mathrm{~mol} \mathrm{~L}^{-1} \mathrm{NaNO}_{3}$ and both $\mathrm{Sb}^{\mathrm{III}}$ and $\mathrm{Sb}^{\mathrm{V}}$ with different concentration ratios. The concentration of $\mathrm{Sb}^{\mathrm{III}}$ was $80 \mu \mathrm{g} \mathrm{L}^{-1}$, while the concentration of $\mathrm{Sb}^{\mathrm{V}}$ was set at 80 and $800 \mu \mathrm{g} \mathrm{L}^{-1}$, respectively. To confirm the stability of Sb species, samples of deployment solution were collected and analyzed for the Sb speciation using HPLC-ICP-MS.

Capacity of MSBA-DGT. To measure the capacity of MSBA gels, MSBA-DGT devices with $0.8 \mathrm{~mm}$ thick diffusive gels were deployed for $4 \mathrm{~h}$ in $2 \mathrm{~L}$ of well-stirred $0.01 \mathrm{~mol} \mathrm{~L}^{-1} \mathrm{NaNO}_{3}$ solutions containing $\mathrm{Sb}^{\mathrm{III}}$ at various concentrations $(0.1$ to $35 \mathrm{mg}$ $\mathrm{L}^{-1}$ ). The mass accumulated by MSBA-DGT devices was compared to the theoretical mass calculated from eq S3. Deviation of the measured mass from the theoretical mass indicates that the linear accumulation capacity is exceeded, and the sampler is no longer suitable for the quantitative accumulation of $\mathrm{Sb}^{\mathrm{III}}$.

Distribution of Antimony in MSBA and MFS Binding Gels. In order to investigate the homogeneity of MSBA binding gels for 2D high-resolution analysis, spatial distribution of $\mathrm{Sb}$ in the binding gel was measured using laser ablation (UP-213, New Wave Research, Fremont, CA) coupled with ICP-MS (LA-ICP-MS). 3mercaptopropyl-functionalized silica (MFS) binding gel, ${ }^{27}$ which contains thiol groups, were compared with the MSBA binding gel to assess the uniformity of $\mathrm{Sb}$ immobilisation to the binding gels. After 4-h deployment of both MSBA- and MFSDGT devices in $2 \mathrm{~L}$ of well-stirred solutions containing $50 \mu \mathrm{g} \mathrm{L}^{-1} \mathrm{Sb}^{\mathrm{III}}$ and $0.01 \mathrm{~mol}$ 
$\mathrm{L}^{-1} \mathrm{NaNO}_{3}$, the MSBA and MFS gel layers were dried using a gel drier (Model 583, Bio-rad, USA), with a backing layer comprising of an acid-washed $0.45-\mu \mathrm{m}$ cellulose nitrate filter. Analysis of $\mathrm{Sb}$ at $50 \mu \mathrm{m}$ spatial resolution was performed using LA-ICPMS following a line-scan mode procedure. ${ }^{41,42}$ Briefly, a beam diameter of $50 \mu \mathrm{m}$ was scanned across the gels in a series of lines at $50 \mu \mathrm{m} \mathrm{s}^{-1}$, which covered an area of $\sim 25$ $\mathrm{mm}^{2}$ and contained more than 32400 data points during ICP-MS measurement. $\mathrm{C}^{13}$ was used as an internal standard. The laser-ablation data were plotted as the normalized intensity $\left(\mathrm{Sb}^{121} / \mathrm{C}^{13}\right)$ per unit area of binding gel. Data processing was conducted in Excel, and visualization was accomplished using ImageJ v1.48 software [National Institutes of Health (NIH), Bethesda, MD, https://imagej.nih.gov/ij/].

High-Resolution Measurement in Rice Rhizosphere. Preparation of soil sample and rhizotrons. Soil was collected from the Xikuangshan Sb mine located in Hunan province of China. It was thoroughly mixed, air-dried, and ground to a particle size of $<2 \mathrm{~mm}$. The soil was amended with Sulphur (S) at $100 \mathrm{mg} \mathrm{S} \mathrm{kg}{ }^{-1}$ using $\mathrm{Na}_{2} \mathrm{SO}_{4}$ stock solution and a control of the soil was prepared without amendment of S. Soil pH values were measured after shaking in $0.05 \mathrm{~mol} \mathrm{~L}^{-1} \mathrm{CaCl}_{2}$ solution with a soil to solution ratio of 1:5 for $1 \mathrm{~h}$. Total organic carbon contents in the soils were determined using a total carbon analyzer (Vario TOC, Elementar, Germany). Concentrations of other elements in soils were determined by ICP-MS (PerkinElmer, USA) after digestion using a Hot Block Digestion System (Environmental Express, USA) following EPA Method 3050B. Water-extractable concentrations of elements were 
obtained in a solid to liquid ratio of 1:10 using a rotary shaker for $24 \mathrm{~h} .^{8}$

Treated soil samples were incubated for 30 days before being packed into the rhizotrons $^{32,} 33,42$ and maintained at $\sim 100 \%$ water holding capacity (WHC) before seedling transplantation. After sterilization in $0.5 \% \mathrm{NaOCl}$ for $10 \mathrm{~min}$, rice seeds were rinsed with deionized water and germinated at $25^{\circ} \mathrm{C}$ for one week. Rice seedlings were transplanted close to the front window of the rhizotrons for a further 2-3 weeks, which were kept at an inclination of $30-45^{\circ}$ to ensure that roots developed alongside the front window of rhizotron (Figure S2). During rice cultivation, the rooting zone was kept in darkness and deoxygenated with nitrogen gas to minimize ingress of $\mathrm{O}_{2}$.

Chemical imaging in the rhizosphere. To demonstrate the utility of the newly synthesized MSBA gel, the ultrathin MSBA binding gel and AgI binding gel ${ }^{43,44}$ was used to measure the distribution of $\mathrm{Sb}^{\mathrm{III}}$ and dissolved sulfide in a rice rhizosphere. To be specific, an AgI gel was firstly deployed within the rice rhizosphere for $24 \mathrm{~h}$ and then an ultrathin MSBA gel was attached with tape to the inside of the transparent rhizotrons for $24 \mathrm{~h}$. A layer of $0.2-\mu \mathrm{m}$ pore size and $10-\mu \mathrm{m}$ thick polycarbonate membrane (Nuclepore, Whatman, Maidstone, UK) was used to maintain the soil uniformity during deployment and avoid disturbance to roots and soil when the front plate was removed. The AgI gels were scanned by a flat-bed computer scanner to provide a grey-scale image of sulfide (see SI for detailed information). The MSBA gels used in this rhizosphere experiment were analyzed using LA-ICP-MS to obtain DGT measured metal fluxes, $f_{\text {DGT }}\left(\mathrm{pg} \mathrm{cm}^{-2} \mathrm{~s}^{-1}\right)$, mainly determined by the labile 
concentration adjacent to the gel surface. It was calculated based on the accumulation mass of metals in the gel and the deployment time. The set-up of LA-ICP-MS and analysis of the ultrathin MSBA gel after deployment were performed as described above. Line scans of the gels were conducted at a scanning speed of $300 \mu \mathrm{m} \mathrm{s}^{-1}$, a scan line interval of $150 \mu \mathrm{m}$, a beam diameter of $100 \mu \mathrm{m}$, and a repetition rate of $5 \mathrm{~Hz}$. The laser data obtained from LA-ICP-MS measurement in gel samples were transformed into accumulation mass $\left(\mathrm{ng} \mathrm{cm}^{-2}\right.$ ) based on the calibration curves (see SI), and visualization was performed using ImageJ v1.48 software.

\section{RESULTS AND DISCUSSION}

DGT Blank Concentration and Method Detection Limit. DGT blank concentration of $\mathrm{Sb}^{\mathrm{III}}$ was achieved by measuring the mass of Sb existing in MSBA binding gel retrieved from the MSBA-DGT device which was assembled and left without deployment for $24 \mathrm{~h}$. DGT blank concentration of $\mathrm{Sb}^{\mathrm{III}}$ obtained in this study was $0.013 \pm 0.006 \mu \mathrm{g} \mathrm{L} \mathrm{L}^{-1}$. The method detection limit (MDL) of $0.02 \mu \mathrm{g} \mathrm{\textrm {L } ^ { - 1 }}$ was calculated as three times the standard deviation of the blank value, assuming that a MSBA-DGT device with a $0.14 \mathrm{~mm}$ thick filter membrane and a $0.8 \mathrm{~mm}$ thick diffusive gel was deployed for $24 \mathrm{~h}$ at $25^{\circ} \mathrm{C}$. The calculated MDL of MSBA-DGT is lower than other DGTs equipped with MFS binding gel reported by Fan et al. $\left(1.99 \mu \mathrm{g} \mathrm{L}^{-1}\right)^{30}$ and Bennett et al. $\left.(0.06 \mu \mathrm{g} \mathrm{L})^{-1}\right)^{31}$. This value is substantially lower than the typical concentration of $\mathrm{Sb}^{\mathrm{III}}$ in surface waters $\left(0.029-0.736 \mu \mathrm{g} \mathrm{L}^{-1}\right)^{45}$ and groundwater $(0.023-$ $\left.0.116 \mu \mathrm{g} \mathrm{L}^{-1}\right){ }^{17}$ Even if concentrations of $\mathrm{Sb}^{\mathrm{III}}$ are lower than MDL, a longer 
deployment period or a thinner diffusive gel layer $(\Delta \mathrm{g}<0.8 \mathrm{~mm})$ could be applied to increase mass accumulation of $\mathrm{Sb}^{\mathrm{III}}$.

Kinetic of Binding and Elution Efficiency. The binding dynamics of $\mathrm{Sb}^{\mathrm{III}}$ and $\mathrm{Sb}^{\mathrm{V}}$ to MSBA gel disc are shown in Figure 1. Mass of accumulated $\mathrm{Sb}^{\mathrm{III}}$ on binding gels increased almost linearly with time in the first $30 \mathrm{~min}$. More than $95 \%$ of the original $\mathrm{Sb}^{\mathrm{III}}$ in solution was bound onto the MSBA gel discs after $120 \mathrm{~min}$. However, less than $5 \%$ of $\mathrm{Sb}^{\mathrm{V}}$ was retained in the MSBA gel disc over the $24 \mathrm{~h}$ exposure. Selective measurement for $\mathrm{Sb}^{\mathrm{III}}$ was achieved by the thiol groups in mesoporous silica, which have a strong affinity for "soft" $\mathrm{Sb}$ III ions and a low affinity for "hard" $\mathrm{Sb}^{\mathrm{V}}$ ions. ${ }^{46}$ The binding rate over the first $30 \mathrm{~min}$ was about $1.97 \mathrm{ng} \mathrm{min}^{-1} \mathrm{~cm}^{-2}$, much higher than the

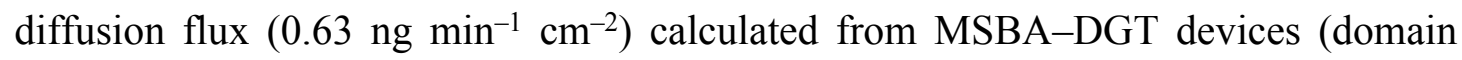
diffusion thickness: $0.89 \mathrm{~mm}$ ) which were assumed to be deployed in $100 \mu \mathrm{g} \mathrm{L}^{-1} \mathrm{Sb}^{\mathrm{III}}$ solutions at $25{ }^{\circ} \mathrm{C}$. Such elevated concentration (up to $100 \mu \mathrm{g} \mathrm{L}^{-1}$ ) reflects an Sb-rich natural background near active mines compared to average Sb concentrations in world rivers $\left(1 \mu \mathrm{g} \mathrm{L}^{-1}\right) .^{2}$ It suggests that MSBA gels can uptake $\mathrm{Sb}^{\mathrm{III}}$ rapidly with high selectivity to ensure its concentration at the interface between the binding gel and the diffusive gel being effective zero, meeting the requirement of DGT theory and justifying eq $\mathrm{S} 3$ for further measurement of $\mathrm{Sb}^{\mathrm{III}}$.

A reproducible elution efficiency of $\mathrm{Sb}^{\mathrm{III}}$ from the MSBA binding gels is essential for DGT measurement. It is documented that $\mathrm{KIO}_{3}$ and $\mathrm{HNO}_{3}$ is an ideal elution for $\mathrm{Se}^{\mathrm{IV}}$ from mercapto, amino bifunctionalized SBA15 mesoporous silica nanoparticle 
(SBA) based binding gel ${ }^{29}$ and As ${ }^{\mathrm{III}}$ from MFS based binding gel. ${ }^{27}$ In this study, three different eluents were tested for MSBA binding gel discs with different masses of loaded $\mathrm{Sb}^{\text {III }}$. Uptake efficiencies of binding gels in solutions across a series of exposure concentrations $\left(50-500 \mu \mathrm{g} \mathrm{L}^{-1}\right)$ were $>99 \%$ after $24 \mathrm{~h}$. As shown in Table S3, when the $\mathrm{Sb}^{\mathrm{III}}$ accumulation mass ranged between $0.5-5 \mu \mathrm{g}$ per gel disc, using $3 \mathrm{~mL}$ of $1 \mathrm{M}$ $\mathrm{HNO}_{3}+1 \% \mathrm{KIO}_{3}(\mathrm{~m} / \mathrm{v})$ can achieve the consistent elution efficiency of 95.4-96.8\%, with the average value of $96.2 \%$. But the elution efficiency obtained using $1 \mathrm{~mL}$ of 1 $\mathrm{M} \mathrm{HNO}_{3}+1 \% \mathrm{KIO}_{3}(\mathrm{~m} / \mathrm{v})$ was not consistent, decreasing from $92.2 \%$ to $68.4 \%$ with the increasing accumulation of $\mathrm{Sb}^{\mathrm{III}}$. This might be because the content of $\mathrm{KIO}_{3}$ was not enough to break the binding between thiol groups and $\mathrm{Sb}^{\mathrm{III}}$. This elution efficiency of $\mathrm{Sb}^{\mathrm{III}}$ using $3 \mathrm{~mL}$ of $1 \mathrm{M} \mathrm{HNO}_{3}+1 \% \mathrm{KIO}_{3}(\mathrm{~m} / \mathrm{v})$ is comparable to that of SBA gels for $\mathrm{Se}^{\mathrm{IV}}(97.0 \%),{ }^{29}$ but higher than MFS gel for $\mathrm{As}^{\mathrm{III}}(85.6 \%)$ and $\mathrm{Sb}^{\mathrm{III}}(62.6 \%) .{ }^{27,} 31$ However, $1 \mathrm{M} \mathrm{HNO}_{3}$ failed to elute the $\mathrm{Sb}^{\mathrm{III}}$ from the binding gel, which may prove that $\mathrm{Sb}$ is chelated with thiol groups via chemisorption ${ }^{47}$ rather than ion exchange.

Effects of pH and Ionic Strength on MSBA-DGT performance. Effects of $\mathrm{pH}$ on the MSBA-DGT measurement of $\mathrm{Sb}^{\mathrm{III}}$ are shown in Figure $2 \mathrm{a}$. The ratio $\left(C_{\mathrm{DGT}} / C_{\text {soln }}\right)$ of the DGT-measured concentration of $\mathrm{Sb}^{\mathrm{III}}, C_{\mathrm{DGT}}$, to $\mathrm{Sb}^{\mathrm{III}}$ concentration in the deployment solution, $C_{\text {soln }}$, was reproducible within an acceptable limit $(1.0 \pm 0.1)$ for $\mathrm{pH}$ ranging from 3.2 to 9.1. Meanwhile, effects of $\mathrm{pH}$ on the accumulation of $\mathrm{Sb}^{\mathrm{V}}$ by MSBA-DGT was assessed to ensure that this device remained selective for $\mathrm{Sb}^{\mathrm{III}}$ over a range of environmentally relevant $\mathrm{pH}$. As shown in Table $\mathrm{S} 4$, the $C_{\mathrm{DGT}} / C_{\text {soln }}$ of $\mathrm{Sb}^{\mathrm{V}}$ 
measured by MSBA-DGT in the $\mathrm{pH}$ range of 4-9 was comparable, about $0.03-0.06$, indicating that $\mathrm{pH}$ impacts on the selectivity of MSBA-DGT in this range were negligible. However, as reported by Bennett et al. (2016) ${ }^{31}$, MFS-DGT presented adsorption for $\mathrm{Sb}^{\mathrm{V}}$ at $\mathrm{pH}<7$, expressed as the $C_{\mathrm{DGT}} / C_{\text {soln }}$ of $\mathrm{Sb}^{\mathrm{V}}$ reached at 0.82 at $\mathrm{pH}$ of 4.06. In this work, MSBA-DGT provided good selectivity and an accurate prediction for $\mathrm{Sb}^{\mathrm{III}}$ in the environment relevant $\mathrm{pH}$ range of 4-9, indicating a good application prospect in natural systems.

As shown in Figure $2 \mathrm{~b}$, measurements of $\mathrm{Sb}^{\mathrm{III}}$ by MSBA-DGT were not significantly influenced by ionic strength in solutions containing $0.1-200 \mathrm{mmol} \mathrm{L}^{-1}$ $\mathrm{NaNO}_{3}$, with all average $C_{\text {DGT }} / C_{\text {soln }}$ values between $0.94-1.03$. A similar phenomenon has been previously observed for the MFS-DGT used to selectively measure $\mathrm{Sb}^{\mathrm{III}} .{ }^{30,31}$ It has been reported that the specific adsorption of thiol groups for $\mathrm{Sb}^{\mathrm{III}}$ is free of ionic strength interference, ${ }^{47}$ which supported the good performance of MSBA-DGT and MFS-DGT in solution with high ionic strength. ${ }^{31}$ These results suggest that the MSBADGT technique qualifies as an accurate measurement of $\mathrm{Sb}^{\mathrm{III}}$ in the majority of fresh and marine waters. Overall, the novel MSBA-DGT device is applicable for in situ $\mathrm{Sb}^{\mathrm{III}}$ measurement in the environment with $\mathrm{pH}$ of 4-9 considering jointly selectivity and accuracy and ionic strength of $0.1-200 \mathrm{mmol} \mathrm{L}^{-1}$.

Validation of Selective Measurement of $\mathbf{S b}^{\mathrm{III}}$. The robustness and selectivity of MSBA-DGT in long-time deployment is a prerequisite of its application in the real field scenario. The linear selective accumulation of $\mathrm{Sb}^{\mathrm{III}}$ with the deployment time by 
MSBA-DGT demonstrates that DGT can predict time-averaged solution concentrations based on the accumulated mass of $\mathrm{Sb}$ in the MSBA gels (Figure 3). Nevertheless, the accumulated mass of $\mathrm{Sb}^{\mathrm{V}}$ in the binding gels was negligible $(<2.7 \%$ of $\mathrm{Sb}^{\mathrm{III}}$ ) within the deployment time up to $72 \mathrm{~h}$ and the measured negligible amount of $\mathrm{Sb}^{\mathrm{V}}$ probably resulted from the diffusional equilibrium between the deployment solution and the liquid phase in the MSBA gel. It indicates the MSBA DGT device has a good selectivity for $\mathrm{Sb}^{\mathrm{III}}$. To ensure accurate results, it is suggested that the MSBA gel be washed using Milli-Q water to lower the amount of the remaining $\mathrm{Sb}^{\mathrm{V}}$ before elution.

In natural waters, given that $\mathrm{Sb}^{\mathrm{V}}$ is the dominant form over most natural environment, ${ }^{48} \mathrm{Sb}^{\mathrm{V}}$ might influence the accuracy of $\mathrm{Sb}^{\mathrm{III}}$ measurement by MSBA-DGT due to (a) the diffusional equilibrium for $\mathrm{Sb}^{\mathrm{V}}$ between deployment solution and the liquid phase in the binding gel and (b) the interference of $\mathrm{Sb}^{\mathrm{V}}$ on the specific binding between $\mathrm{Sb}^{\mathrm{III}}$ and the binding gel. To further evaluate the selectivity, MSBA-DGT devices were deployed in $2 \mathrm{~L}$ of solutions containing both $\mathrm{Sb}^{\mathrm{III}}$ and $\mathrm{Sb}^{\mathrm{V}}$ in $0.01 \mathrm{~mol} \mathrm{~L}^{-1}$ $\mathrm{NaNO}_{3}$. As shown in Table $\mathrm{S} 5, C_{\mathrm{DGT}} / C_{\text {soln }}$ values were reproducible in the limit range of $1.0 \pm 0.1$ when the ratio of $\mathrm{Sb}^{\mathrm{V}}$ to $\mathrm{Sb}^{\mathrm{III}}$ concentration increased from 1 to 50 . But the $C_{\mathrm{DGT}} / C_{\text {soln }}$ value was slightly higher than 1.10 at the $\mathrm{Sb}^{\mathrm{V}} / \mathrm{Sb}^{\mathrm{III}}$ concentration ratio of 100 . This might be mainly attributed to the high concentration of $\mathrm{Sb}^{\mathrm{V}}$ in the liquid phase of the binding gel as a result of diffusional equilibrium (not adsorption by the binding gel). The results imply that $\mathrm{Sb}^{\mathrm{V}}$ will not interfere with the selectivity of MSBA-DGT for 
$\mathrm{Sb}^{\mathrm{III}}$ when $\mathrm{Sb}^{\mathrm{V}}$ accounts for lower than $98 \%$ of the total species content. To overcome the potential over-estimation of $\mathrm{Sb}^{\mathrm{III}}$ caused by diffusional equilibrium of $\mathrm{Sb}^{\mathrm{V}}$ between binding gel and natural waters, it is recommended that the binding gel is washed by immersing in MQ water several times before elution.

Capacity of MSBA-DGT. Enough capacity is the guarantee of long-term deployment of DGT technique. The measured mass of $\mathrm{Sb}^{\mathrm{III}}$ in MSBA-DGT increased linearly with the increasing solution concentrations ranging from 0.1 to $17 \mathrm{mg} \mathrm{L}^{-1}$ (Figure S3), fitting well with the theoretical line calculated using eq S3 based on Sb ${ }^{\text {III }}$ concentration in the deployment solution. However, when the concentration of $\mathrm{Sb}^{\mathrm{III}}$ reached at $24 \mathrm{mg} \mathrm{L}^{-1}$, the DGT measured concentration was $77 \%$ of the solution concentration. Results of this experiments imply that MSBA-DGT exhibits linear accumulation capacity of $65 \mu \mathrm{g}$ per disc for $\mathrm{Sb}^{\mathrm{III}}$, comparable to that reported for $\mathrm{As}^{\mathrm{III}}$ $(77.5 \mu \mathrm{g})^{27}$ and $\mathrm{Sb}^{\mathrm{III}}(100 \mu \mathrm{g})^{31}$ of MFS binding gel layers. In addition, this capacity makes MSBA-DGT being able to be deployed in $3 \mathrm{mg} \mathrm{L}^{-1} \mathrm{Sb}^{\mathrm{III}}$-contaminated water, which is not common, for $24 \mathrm{~h}$ at $25^{\circ} \mathrm{C}$. If the concentration of $\mathrm{Sb}^{\mathrm{III}}$ in water is lower than the Chinese maximum limit value of $5 \mu \mathrm{g} \mathrm{\textrm {L } ^ { - 1 }}$ for water quality, ${ }^{49}$ the measured capacity in this study would be reached after 1.4 years of deployment when only time was taken into account. It means that the capacity of MSBA-DGT can support the longterm monitoring of $\mathrm{Sb}^{\mathrm{III}}$.

High-resolution Performance of MSBA Binding Gels. The resolution of DGT binding gels and their feasibility to be applied as high-resolution sampling approaches 
were mainly determined by the homogeneity of binding material distributions in the hydrogels. The benefit of using a binding gel with high resolution relates to the ability to generate a stable signal due to the high frequency of measurements, which is especially important when working with small sample areas. The scan images of the binding gels captured by LA-ICP-MS are shown in Figures 4a and 4b. The MFS resin beads were unevenly dispersed on the MFS gel surface while no visible graininess on the MSBA gel was observed even at a resolution of $50 \mu \mathrm{m}$.

Here, we quantitatively compared the homogeneity of MSBA binding gel with commercial MSF binding gels using LA-ICP-MS analysis to demonstrate the merits of MSBA binding gels in high-resolution analysis. Both the MSBA-DGT and MSFDGT were deployed in the same solution and then the distribution characteristics of $\mathrm{Sb}$ in the binding gels were analyzed using $\mathrm{LA}-\mathrm{ICP}-\mathrm{MS}$ at the same measurement resolution of $50 \mu \mathrm{m}$. Theoretically, the signal of Sb should be constant during LA-ICPMS analysis, while the stability drift can be caused by matrix heterogeneity and instrumental deviation (such as laser defocusing and instable aerosol transport efficiency). Figures $4 \mathrm{c}$ and $4 \mathrm{~d}$ present the $2 \mathrm{D}$ mapping of intensity ratios $\left(\mathrm{Sb}^{121} / \mathrm{C}^{13}\right)$ during line scanning produced with a $50-\mu \mathrm{m}$ laser beam diameter. $\mathrm{C}^{13}$ was used as an internal standard to compensate for fluctuations in sensitivity due to sample transport and plasma stability. ${ }^{50}$ Then the heterogeneity of binding resin distribution in the matrix becomes the major factor determining the deviation of normalized signal $\mathrm{Sb}^{121} / \mathrm{C}^{13}$.

The MFS gel exhibited heterogeneous distribution of intensity ratios of $\mathrm{Sb}^{121} / \mathrm{C}^{13}$ 
while the MSBA gel presented an even distribution in the sampling area of $5 \times 5 \mathrm{~mm}^{2}$ (Figures $4 \mathrm{c}$ and $4 \mathrm{~d}$ ). To be specific, the RSD values of $\mathrm{Sb}^{121} / \mathrm{C}^{13}$ are $68.3 \%$ and $9.2 \%$ for the MFS and MSBA gel, respectively, in a total number of 32400 data points. Such high standard deviation would lower the accuracy of LA-ICP-MS analysis, limiting the application of MSF binding gels in high resolution sampling. Also, the frequency distribution histogram demonstrated that the signal ratio of MSBA gel gathered in the range of 3-4, while that of MFS gel exhibited more dispersive distribution (Figures 4f). The difference of particle size between MFS and MSBA is a dominant factor influencing the signal stability during LA-ICP-MS analysis. MFS resin has the relatively large bead size $(\sim 65 \mu \mathrm{m})$ (Figure S4) and operationally caused obvious uneven distribution of MFS in the binding gels. For MSBA resins, however, it seems that their fine sizes $(\sim 3.4 \mu \mathrm{m})$ (Figure S4) can make them evenly-distributed in the binding gels. This comparison between the MSBA and MFS gels indicated that the MSBA gel is sufficiently reproducible for getting quantitative results during high resolution analysis.

In Situ 2D Profiles in the Rhizosphere. The high-resolution profiles of DGTmeasured $\mathrm{Sb}^{\mathrm{III}}$ and dissolved sulfide fluxes of the soil-root interface were obtained to give an insight of $\mathrm{Sb}^{\mathrm{III}}$ spatial variability and $\mathrm{S}$ application induced solubilization hotspots in the rhizosphere of rice. As expected, compared with the control soil (Soil C), labile concentrations of sulfide were higher in $\mathrm{S}$ treated soil (Soil S) as a direct consequence of sulfate reduction reactions as well as the increased activities of sulfate- 
reducing bacteria with $\mathrm{S}$ application. The product of dissimilatory sulfate reduction, sulfide, dominates most of the sulfur pool. ${ }^{51}$ Similar to the change of sulfide labile flux with $\mathrm{S}$ addition, $\mathrm{Sb}^{\mathrm{III}}$ labile fluxes were slightly higher in the Soil $\mathrm{S}$ than Soil C (Figure 5), congruent with the elevated $\mathrm{Sb}$ concentration in soil solution of Soil S (Table S2). When we focus on the spatial characteristics of $\mathrm{Sb}^{\mathrm{III}}$ labile fluxes, a localized process of mobilization of $\mathrm{Sb}^{\mathrm{III}}$ was seen in the rhizosphere along the root axis, especially at the root tip zones, which is consistent with what has been observed previously with other metal elements. ${ }^{33,52}$ The observation of a distinct peak of $\mathrm{Sb}^{\mathrm{III}}$ flux close to the root surface may be partly linked to root exudation ${ }^{53}$ and differences in the microbial habitat.

The enhanced DGT-measured $\mathrm{Sb}^{\mathrm{III}}$ flux in Soil S might be associated with the increased dissolved sulfide under controlled anoxic soil. A previous study has been reported that reducing sulfur ( $\left.\mathrm{S}^{2-}\right)$ that is likely to occur in anoxic conditions acts as a reducing agent. This then controls the redox transformation of $\mathrm{Sb}^{\mathrm{V}}$ to the more toxic

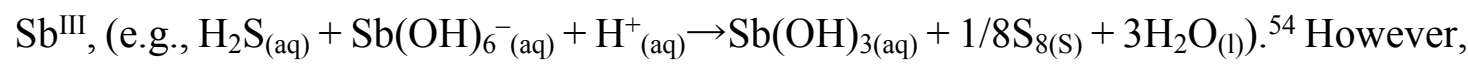
it has also been reported that mobility of $\mathrm{Sb}$ is lower in the absence of active sulfidic subsoil with flooding. ${ }^{55}$ Since the understanding of the fate, behavior, and risks associated with $\mathrm{Sb}$ in soil systems is limited, further targeted investigations on the modes and behaviors of S-induced changes in the rhizosphere of rice are recommended. The newly developed MSBA-DGT will be a valid tool for in situ investigation of $\mathrm{Sb}$ behavior, providing detailed mechanistic and quantitative insight into associated $\mathrm{Sb}$ speciation dynamics in soils. 


\section{CONCLUSIONS}

This work established a synthesized nanoparticle silica based MSBA-DGT for in situ, selective, and high-resolution monitoring of $\mathrm{Sb}^{\mathrm{III}}$ in various environmental media. The high susceptibility of $\mathrm{Sb}^{\mathrm{III}}$ to redox change necessitates the application of low disturbance and in situ sampling method for measurement of $\mathrm{Sb}^{\mathrm{III}}$ bioavailability. The in situ method presented here can selectively capture $\mathrm{Sb}^{\mathrm{III}}$ even in the presence of $\mathrm{Sb}^{\mathrm{V}}$, which makes it a promising tool to characterize $\mathrm{Sb}$ speciation in natural systems. It also exhibited stable and accurate measurement of $\mathrm{Sb}^{\mathrm{III}}$ throughout a wide range of environmental conditions ( $\mathrm{pH} 4-9$, ionic strength $0.1-200 \mathrm{mmol} \mathrm{L}^{-1} \quad \mathrm{NO}_{3}{ }^{-}$). Furthermore, the homogenous binding gel made from the nano-sized MSBA resin enables its targeted application across environmental interfaces to reveal the change of $\mathrm{Sb}^{\text {III }}$ lability at submillimeter scales. The development of this approach would be efficient to fill the gap of our understanding on Sb speciation and bioavailability in natural systems.

\section{ASSOCIATED CONTENT}

\section{Supporting Information}

The Supporting Information is available free of charge on the ACS Publications website at:

Detailed principles of DGT, synthesis of mercapto-functionalized SBA-15 mesoporous silica (MSBA), computer imaging densitometry analysis of AgI gel, standard calibration and limit of detection (LOD) for MSBA binding gel, LA-ICP-MS 
analysis, operation parameters of ICP-MS system, physical and chemical properties of the soil, elution efficiencies of MSBA gels, effects of $\mathrm{pH}$ on the $\mathrm{Sb}^{\mathrm{V}}$ accumulation in MSBA-DGT, validation of selective measurement of Sb"II, TEM image of MSBA nanoparticles, scheme of rhizotron, adsorption capacity of MSBA-DGT, particle size distributions of MSBA and commercial mercapto functionalized silica (MFS), standard calibrations between grey scale values and sulfide content in AgI binding gel, and the plot file of $\mathrm{Sb}^{\mathrm{III}}$ labile flux $\left(\mathrm{pg} \mathrm{cm}^{-2} \mathrm{~s}^{-1}\right)$ as a function of the distance from the root centre.

\section{AUTHOR INFORMATION}

\section{Corresponding Author}

*Phone: 0086-25-89680632. E-mail: esluojun@nju.edu.cn

\section{Notes}

The authors declare no competing financial interest.

\section{ACKNOWLEDGMENTS}

This work was supported by National Key Research and Development Plans of Special Project for Site soils (No. 2018YFC1800602), Major Science and Technology Program for Water Pollution Control and Treatment (No. 2017ZX07302-001), and the National Natural Science Foundation of China (No. 417712717 \& No. 41807023) and the Jiangsu Province Natural Science Foundation (No. BK20180344).

\section{REFERENCES}

1. Council of the European Communities. Council Directive 76/Substances 
Discharged into Aquatic Environment of the Community; Official Journal L 129, 1976; pp 23-29.

2. He, M.; Wang, X.; Wu, F.; Fu, Z. Antimony pollution in China. Sci.Total Environ. 2012, 421, 41-50.

3. He, M.; Wang, N.; Long, X.; Zhang, C.; Ma, C.; Zhong, Q.; Wang, A.; Wang, Y.; Pervaiz, A.; Shan, J., Antimony speciation in the environment: Recent advances in understanding the biogeochemical processes and ecological effects. J. Environ. Sci. 2019, 75, 14-39.

4. USEPA, Water Related Fate of the 129 Priority Pollutants; USEPA: Washington, DC, 1979; Vol. 1.

5. Okkenhaug, G.; Amstatter, K.; Bue, H. L.; Cornelissen, G.; Breedveld, G. D.; Henriksen, T.; Mulder, J. Antimony (Sb) contaminated shooting range soil: $\mathrm{Sb}$ mobility and immobilization by soil amendments. Environ. Sci. Technol. 2013, 47 (12), 6431-6439.

6. Filella, M.; Belzile, N.; Chen, Y. W. Antimony in the environment: a review focused on natural waters I. occurrence. Earth-Sci. Rev. 2002, 57 (1-2), 125-176.

7. Westerhoff, P.; Prapaipong, P.; Shock, E.; Hillaireau, A. Antimony leaching from polyethylene terephthalate (PET) plastic used for bottled drinking water. Water Res. 2008, 42 (3), 551-556.

8. Okkenhaug, G.; Zhu, Y. G.; Luo, L.; Lei, M.; Li, X.; Mulder, J. Distribution, speciation and availability of antimony $(\mathrm{Sb})$ in soils and terrestrial plants from an 
active Sb mining area. Environ. Pollut. 2011, 159 (10), 2427-2434.

9. Pierart, A.; Shahid, M.; Sejalon-Delmas, N.; Dumat, C. Antimony bioavailability: knowledge and research perspectives for sustainable agricultures. J. Hazard. Mater. 2015, 289, 219-234.

10. Okkenhaug, G.; Zhu, Y. G.; He, J. W.; Li, X.; Luo, L.; Mulder, J. Antimony (Sb) and arsenic (As) in Sb mining impacted paddy soil from Xikuangshan, China: differences in mechanisms controlling soil sequestration and uptake in rice. Environ. Sci. Technol. 2012, 46 (6), 3155-3162.

11. Krachler, M.; Emons, H.; Zheng, J. Speciation of antimony for the 21st century: promises and pitfalls. TrAC, Trends Anal. Chem. 2001, 20 (2), 79-90.

12. Saleh, T. A.; Sari, A.; Tuzen, M. Effective adsorption of antimony(III) from aqueous solutions by polyamide-graphene composite as a novel adsorbent. Chem. Eng. J. 2017, 307, 230-238.

13. Zih-Perenyi, K.; Jankovics, P.; Sugar, E.; Lasztity, A. Solid phase chelating extraction and separation of inorganic antimony species in pharmaceutical and water samples for graphite furnace atomic absorption spectrometry. Spectrochim. Acta, Part B 2008, 63 (3), 445-449.

14. Yu, C. H.; Cai, Q. T.; Guo, Z. X.; Yang, Z. G.; Khoo, S. B. Antimony speciation by inductively coupled plasma mass spectrometry using solid phase extraction cartridges. Analyst 2002, 127 (10), 1380-1385.

15. Rivas, R. E.; Lopez-Garcia, I.; Hernandez-Cordoba, M. Speciation of very low 25 
amounts of arsenic and antimony in waters using dispersive liquid-liquid microextraction and electrothermal atomic absorption spectrometry. Spectrochim. Acta, Part B 2009, 64 (4), 329-333.

16. Luo, J. M.; Luo, X. B.; Crittenden, J.; Qu, J. H.; Bai, Y. H.; Peng, Y.; Li, J. H. Removal of antimonite ( $\mathrm{Sb}(\mathrm{III}))$ and antimonate $(\mathrm{Sb}(\mathrm{V}))$ from aqueous solution using carbon nanofibers that are decorated with zirconium oxide ( $\mathrm{ZrO} 2)$. Environ. Sci. Technol. 2015, 49 (18), 11115-11124.

17. Awe, S. A.; Sundkvist, J. E.; Bolin, N. J.; Sandstrom, A. Process flowsheet development for recovering antimony from Sb-bearing copper concentrates. Miner. Eng. 2013, 49, 45-53.

18. Ulrich, N. Determination of antimony species with fluoride as modifier and flow injection hydride generation inductively-coupled plasma emission spectrometry. Anal. Chim. Acta 2000, 417, 201-209.

19. Borch, T.; Kretzschmar, R.; Kappler, A.; Van Cappellen, P.; Ginder-Vogel, M.; Voegelin, A.; Campbell, K. Biogeochemical redox processes and their impact on contaminant dynamics. Environ. Sci. Technol. 2010, 44 (1), 15-23.

20. Wang, L. Y.; Ye, L.; Yu, Y. Q.; Jing, C. Y. Antimony redox biotransformation in the subsurface: effect of indigenous $\mathrm{Sb}(\mathrm{V})$ respiring microbiota. Environ. Sci. Technol. 2018, 52 (3), 1200-1207.

21. Deng, H.; Luo, M.; Shi, X.; Williams, P. N.; Li, K.; Liu, M.; Fan, W.; Xiao, T.; Chen, Y.; Ma, L. Q.; Luo, J. In situ measurement of thallium in natural waters by 
a technique based on diffusive gradients in thin films containing a $\delta$-MnO2 gel layer. Anal. Chem. 2019, 91 (2), 1344-1352.

22. Zhang, S.; Williams, P. N.; Zhou, C. Y.; Ma, L. Q.; Luo, J. Extending the functionality of the slurry ferrihydrite-DGT method: performance evaluation for the measurement of vanadate, arsenate, antimonate and molybdate in water. Chemosphere 2017, 184, 812-819.

23. Pelcova, P.; Docekalova, H.; Kleckerova, A. Determination of mercury species by the diffusive gradient in thin film technique and liquid chromatography - atomic fluorescence spectrometry after microwave extraction. Anal. Chim. Acta 2015, 866, 21-26.

24. Guan, D. X.; Williams, P. N.; Luo, J.; Zheng, J. L.; Xu, H. C.; Cai, C.; Ma, L. Q. Novel precipitated zirconia-based DGT technique for high-resolution imaging of oxyanions in waters and sediments. Environ. Sci. Technol. 2015, 49 (6), 36533661.

25. Han, C.; Williams, P. N.; Ren, J.; Wang, Z.; Fang, X.; Xu, D.; Xie, X.; Geng, J.; Ma, L. Q.; Luo, J. In situ sampling and speciation method for measuring dissolved phosphite at ultratrace concentrations in the natural environment. Water Res. 2018, $137,281-289$.

26. Davison, W.; Zhang, H., In situ speciation measurements of trace components in natural waters using thin-film gels. Nature 1994, 367 (6463), 546-548.

27. Bennett, W. W.; Teasdale, P. R.; Panther, J. G.; Welsh, D. T.; Jolley, D. F. 27 
Speciation of dissolved inorganic arsenic by diffusive gradients in thin films: selective binding of AsIII by 3-mercaptopropyl-functionalized silica gel. Anal. Chem. 2011, 83 (21), 8293-8299.

28. Pan, Y.; Guan, D. X.; Zhao, D.; Luo, J.; Zhang, H.; Davison, W.; Ma, L. Q. Novel speciation method based on diffusive gradients in thin-films for in situ measurement of CrVI in aquatic systems. Environ. Sci. Technol. 2015, 49 (24), 14267-14273.

29. Shi, X.; Fang, W.; Tang, N.; Williams, P. N.; Hu, X.; Liu, Z.; Yin, D.; Ma, L. Q.; Luo, J. In situ selective measurement of SeIV in waters and soils: diffusive gradients in thin-films with bi-functionalized silica nanoparticles. Environ. Sci. Technol. 2018, 52 (24), 14140-14148.

30. Fan, H. T.; Liu, A. J.; Jiang, B.; Wang, Q. J.; Li, T.; Huang, C. C. Sampling of dissolved inorganic SbIII by mercapto-functionalized silica-based diffusive gradients in thin-film technique. $R S C A d v$. 2016, 6 (4), 2624-2631.

31. Bennett, W. W.; Arsic, M.; Welsh, D. T.; Teasdale, P. R. In situ speciation of dissolved inorganic antimony in surface waters and sediment porewaters: development of a thiol-based diffusive gradients in thin films technique for SbIII. Environ. Sci.:Processes Impacts 2016, 18 (8), 992-998.

32. Kreuzeder, A.; Santner, J.; Scharsching, V.; Oburger, E.; Hoefer, C.; Hann, S.; Wenzel, W. W. In situ observation of localized, sub-mm scale changes of phosphorus biogeochemistry in the rhizosphere. Plant Soil 2018, 424 (1-2), 573- 
589.

33. Williams, P. N.; Santner, J.; Larsen, M.; Lehto, N. J.; Oburger, E.; Wenzel, W.; Glud, R. N.; Davison, W.; Zhang, H. Localized flux maxima of arsenic, lead, and iron around root apices in flooded lowland rice. Environ. Sci. Technol. 2014, 48 (15), 8498-506.

34. Multani, R. S.; Feldmann, T.; Demopoulos, G. P. Antimony in the metallurgical industry: A review of its chemistry and environmental stabilization options. Hydrometallurgy 2016, 164, 141-153.

35. Herath, I.; Vithanage, M.; Bundschuh, J. Antimony as a global dilemma: Geochemistiry, mobility, fate and transport. Environ. Pollut. 2017, 223, 545-559.

36. Ye, L.; Chen, H. Z.; Jing, C. Y. Sulfate-Reducing Bacteria Mobilize Adsorbed Antimonate by Thioantimonate Formation. Environ. Sci. Technol. Let. 2019, 6 (7), 418-422.

37. Devries, C. R.; Wang, F. Y. In situ two-dimensional high-resolution profiling of sulfide in sediment interstitial waters. Environ. Sci. Technol. 2003, 37 (4), 792797.

38. Ren, J. H.; Ma, L. Q.; Sun, H. J.; Cai, F.; Luo, J. Antimony uptake, translocation and speciation in rice plants exposed to antimonite and antimonate. Sci. Total Environ. 2014, 475, 83-89.

39. Zhang, H.; Davison, W. Performance characteristics of diffusion gradients in thin films for the in situ measurement of trace metals in aqueous solution. Anal. Chem. 
1995, 67 (19), 3391-3400.

40. Aguado, J.; Arsuaga, J. M.; Arencibia, A. Influence of synthesis conditions on mercury adsorption capacity of propylthiol functionalized SBA-15 obtained by cocondensation. Microporous Mesoporous Mater. 2008, 109 (1-3), 513-524.

41. Gao, Y.; Van de Velde, S.; Williams, P. N.; Baeyens, W.; Zhang, H. Twodimensional images of dissolved sulfide and metals in anoxic sediments by a novel diffusive gradients in thin film probe and optical scanning techniques. $\operatorname{Tr} A C$, Trends Anal. Chem. 2015, 66, 63-71.

42. Santner, J.; Zhang, H.; Leitner, D.; Schnepf, A.; Prohaska, T.; Puschenreiter, M.; Wenzel, W. W. High-resolution chemical imaging of labile phosphorus in the rhizosphere of Brassica napus L. cultivars. Environ. Exp. Bot. 2012, 77, 219-226.

43. Santner, J.; Larsen, M.; Kreuzeder, A.; Glud, R. N. Two decades of chemical imaging of solutes in sediments and soils - a review. Anal. Chim. Acta 2015, 878, $9-42$.

44. Teasdale, P. R.; Hayward, S.; Davison, W. In situ, high-resolution measurement of dissolved sulfide using diffusive gradients in thin films with computer-imaging densitometry. Anal. Chem. 1999, 71 (11), 2186-2191.

45. Wu, X. D.; Song, J. M.; Li, X. G.; Yuan, H. M.; Li, N. Behaviors of dissolved antimony in the Yangtze River Estuary and its adjacent waters. J. Environ. Monit. 2011, 13 (8), 2292-2303.

46. Fan, H. T.; Sun, W.; Jiang, B.; Wang, Q. J.; Li, D. W.; Huang, C. C.; Wang, K. J.; 
Zhang, Z. G.; Li, W. X. Adsorption of antimony(III) from aqueous solution by mercapto-functionalized silica-supported organic-inorganic hybrid sorbent: mechanism insights. Chem. Eng. J. 2016, 286, 128-138.

47. Besold, J.; Kumar, N.; Scheinost, A. C.; Pacheco, J. L.; Fendorf, S.; PlanerFriedrich, B. Antimonite complexation with thiol and carboxyl/phenol groups of peat organic matter. Environ. Sci. Technol. 2019, 53 (9), 5005-5015.

48. Filella, M.; Williams, P. A.; Belzile, N. Antimony in the environment: knowns and unknowns. Environ. Chem. 2009, 6 (2), 95-105.

49. Ministry of Public Health, Standards for drinking water qulity, China, 2006

50. Warnken, K. W.; Zhang, H.; Davison, W. Analysis of polyacrylamide gels for trace metals using diffusive gradients in thin films and laser ablation inductively coupled plasma mass spectrometry. Anal. Chem. 2004, 76 (20), 6077-6084.

51. Bao, P.; Li, G. X.; Sun, G. X.; Xu, Y. Y.; Meharg, A. A.; Zhu, Y. G., The role of sulfate-reducing prokaryotes in the coupling of element biogeochemical cycling. Sci. Total Environ. 2018, 613-614, 398-408.

52. Hoefer, C.; Santner, J.; Puschenreiter, M.; Wenzel, W. W. Localized metal solubilization in the rhizosphere of Salix smithiana upon sulfur application. Environ. Sci. Technol. 2015, 49 (7), 4522-4529.

53. Ptak, C.; McBride, M. Organically complexed iron enhances bioavailability of antimony to maize (Zea mays) seedlings in organic soils. Environ. Toxicol. Chem. 2015, 34 (12), 2732-2738. 
54. Polack, R.; Chen, Y. W.; Belzile, N. Behaviour of $\mathrm{Sb}(\mathrm{V})$ in the presence of dissolved sulfide under controlled anoxic aqueous conditions. Chem. Geol. 2009, $262(3-4), 179-185$.

55. Tighe, M.; Lockwood, P. V.; Ashley, P. M.; Murison, R. D.; Wilson, S. C. The availability and mobility of arsenic and antimony in an acid sulfate soil pasture system. Sci. Total Environ. 2013, 463, 151-160. 


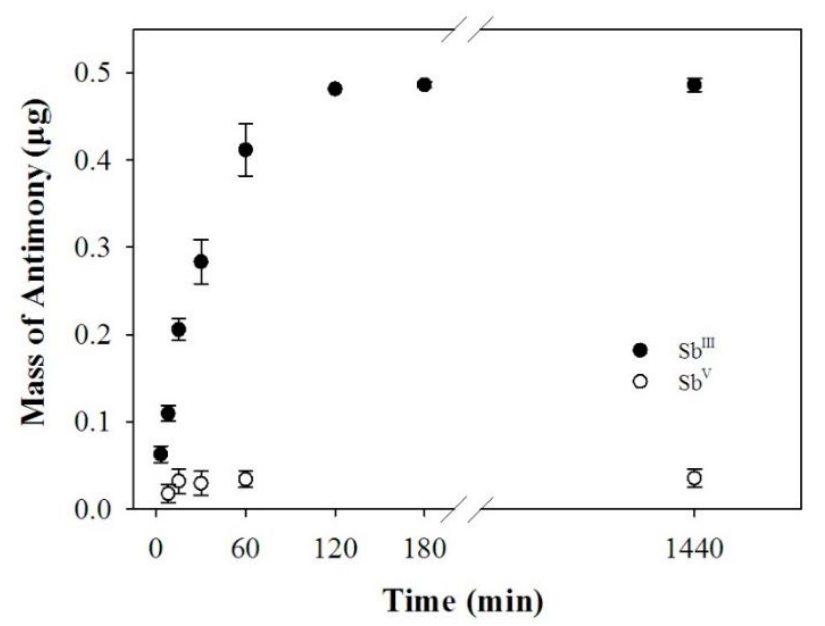

Figure 1. Mass of $\mathrm{Sb}$ accumulated by MSBA binding gel discs soaked in $10 \mathrm{~mL}$ of well-stirred solutions containing $0.01 \mathrm{~mol} \mathrm{~L}^{-1} \mathrm{NaNO}_{3}, 50 \mu \mathrm{g} \mathrm{L}^{-1} \mathrm{Sb}^{\mathrm{III}}$ or $\mathrm{Sb}^{\mathrm{V}}$ for various times ranging from $3 \mathrm{~min}$ to $24 \mathrm{~h}$. Values are means \pm standard deviations of three replicates. 

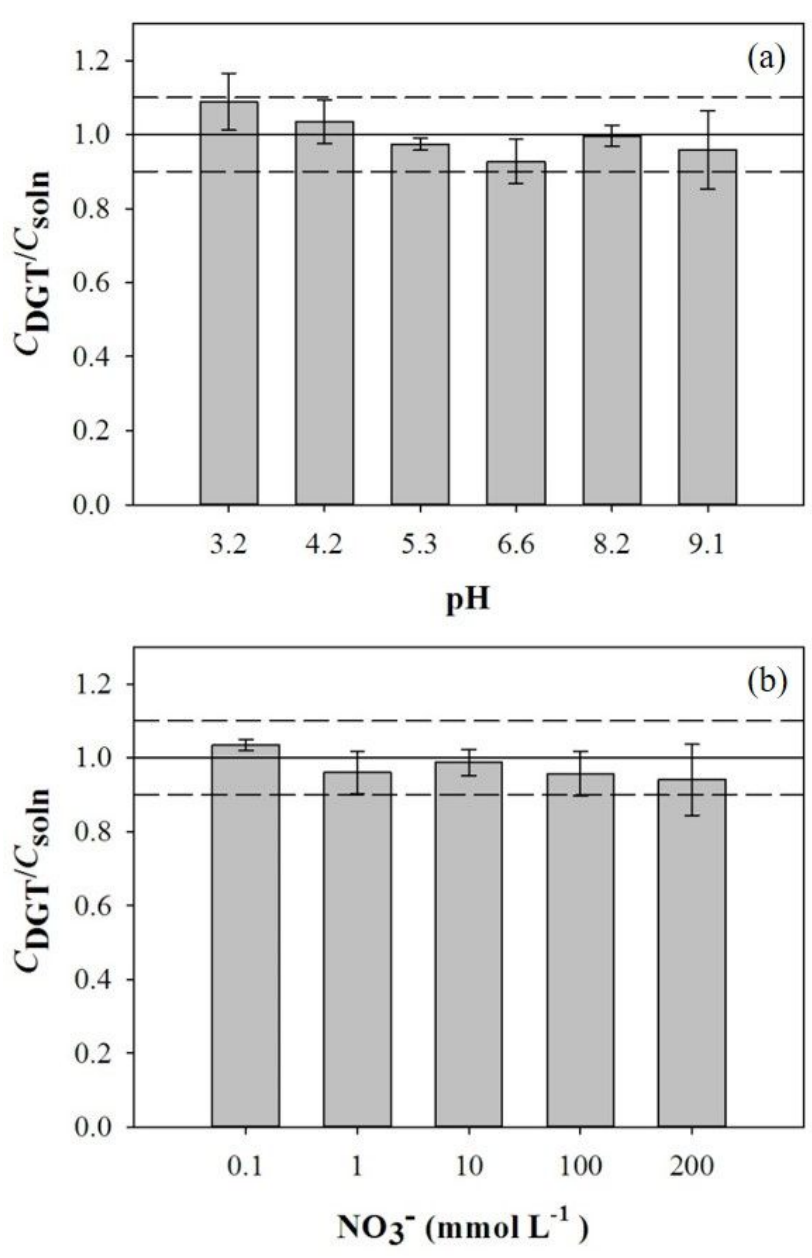

Figure 2. Effects of $\mathrm{pH}$ (a) and ionic strength (b) on the ratio of DGT-measured $\mathrm{Sb}^{\mathrm{III}}$ concentration, $C_{\mathrm{DGT}}$, to its concentration in the bulk solution, $C_{\text {soln }}$. The solid horizontal lines and the dotted horizontal lines represent values of $1.0 \pm 0.1$. Error bars are calculated from the standard deviation of replicates $(n=3)$. 


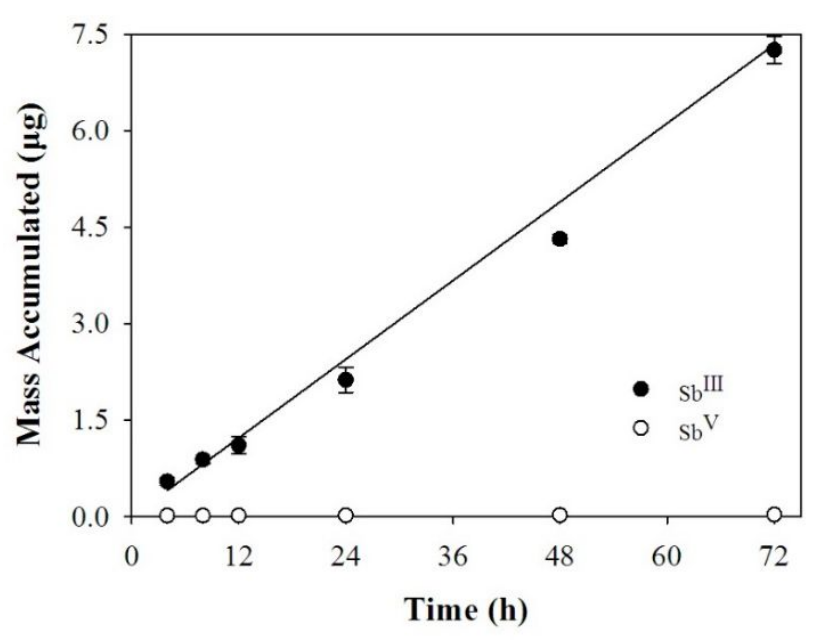

Figure 3. Measured masses of Sb taken up by MSBA-DGT deployed in well-stirred solutions containing either $50 \mu \mathrm{g} \mathrm{L}-1 \mathrm{Sb}^{\mathrm{III}}$ or $50 \mu \mathrm{g} \mathrm{L}-1 \mathrm{Sb}^{\mathrm{V}}$ in $0.01 \mathrm{~mol} \mathrm{~L}^{-1} \mathrm{NaNO}_{3}$ for 4-72 $\mathrm{h}$. The solid line is the theoretical regression predicted by eq S3. Error bars were calculated from at least three replicates. 

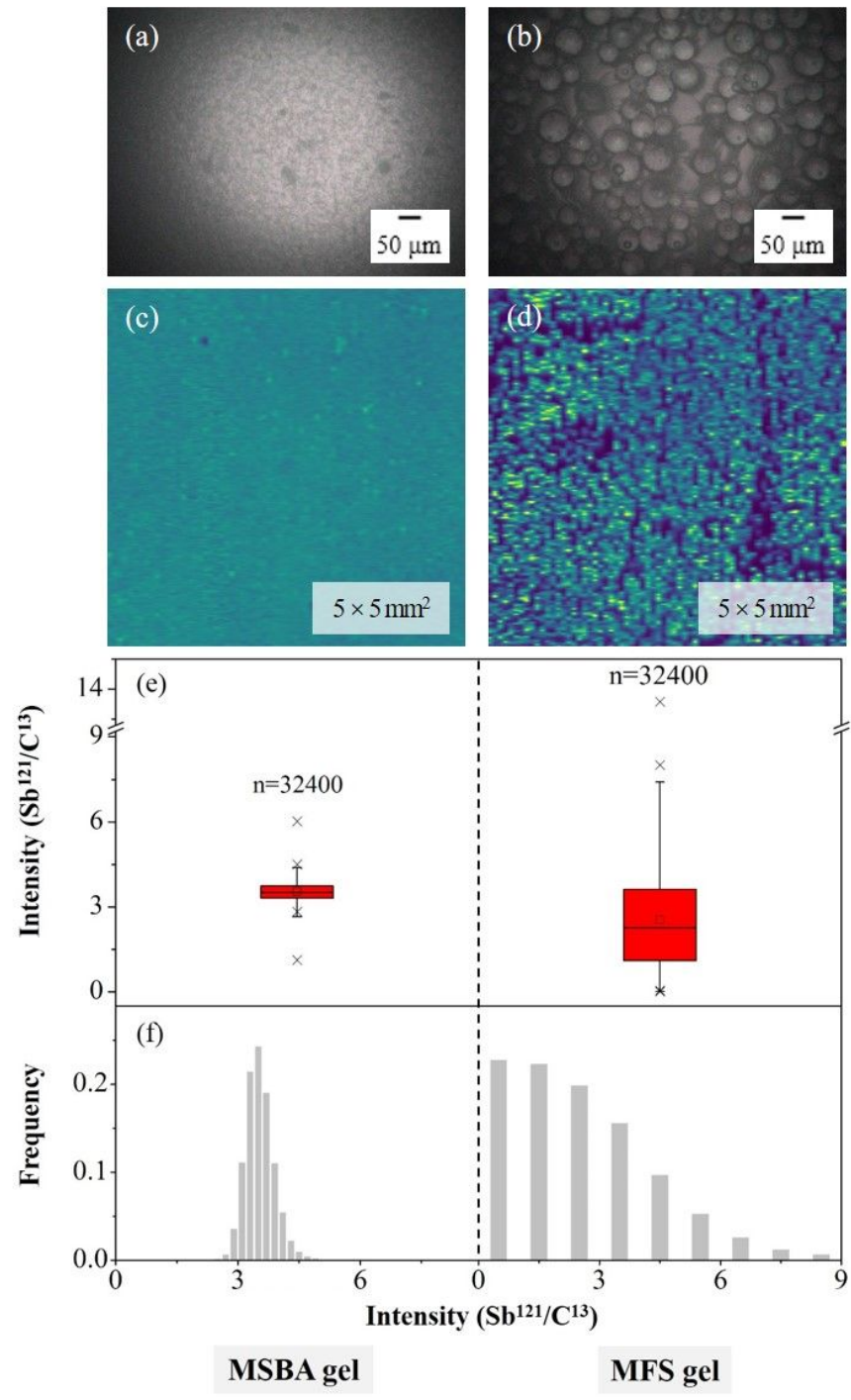

Figure 4. The scan images of MSBA gel (a) and MFS gel (b) captured by LA system. 2D mapping of intensity ratios $\left(\mathrm{Sb}^{121} / \mathrm{C}^{13}\right)$ during line scanning produce using $\mathrm{LA}-\mathrm{ICP}-$ MS (c, d). Signal intensity of $\mathrm{Sb}^{121 / \mathrm{C}^{13}}$ for MSBA gel and MFS gel (e) and the frequency distribution histogram of signal intensities of the two binding gels (f). Boxes represent the $25^{\text {th }}$ to $75^{\text {th }}$ percentiles, solid lines and squares in boxes are the median and mean values, error bars represent the $5^{\text {th }}$ and $95^{\text {th }}$ percentiles, cross symbols represent the $1^{\text {th }}$ and $99^{\text {th }}$ percentiles, respectively (e). 

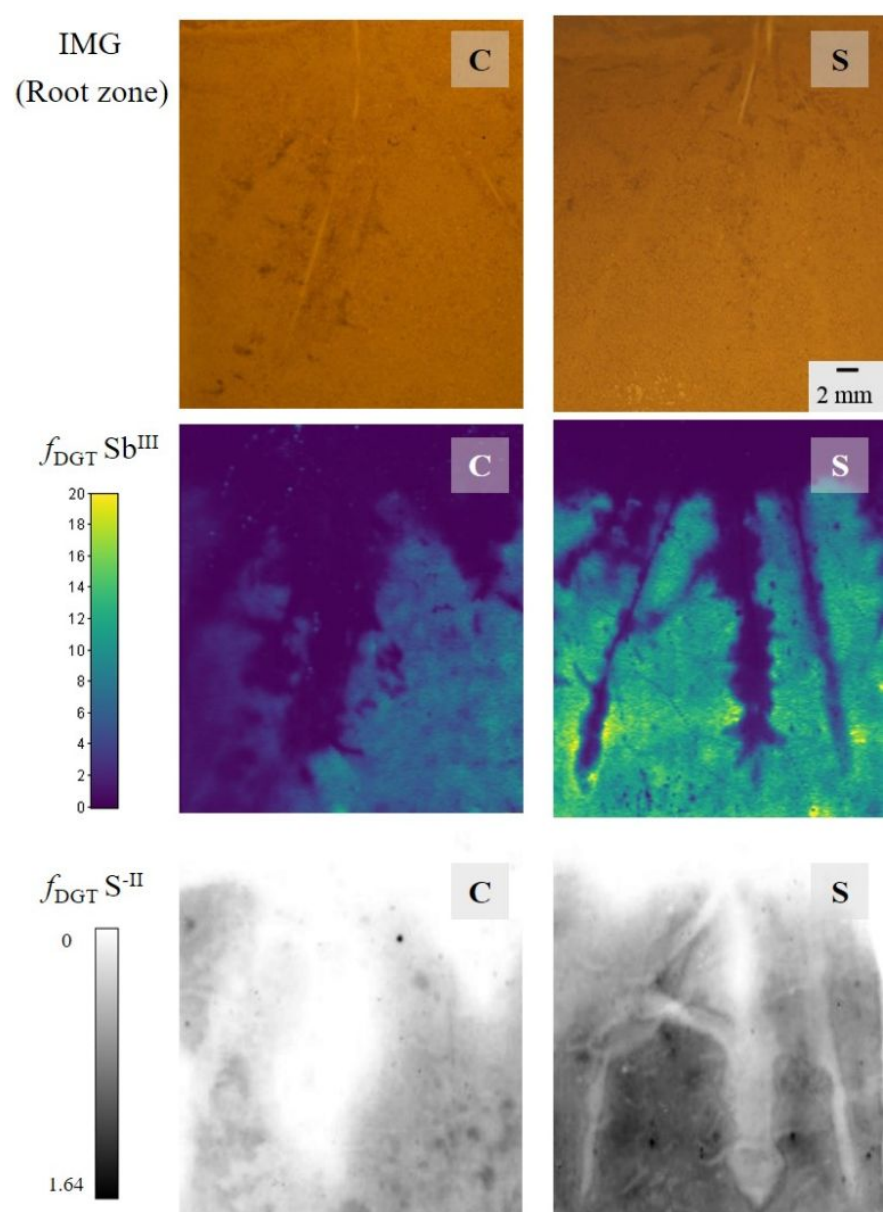

C

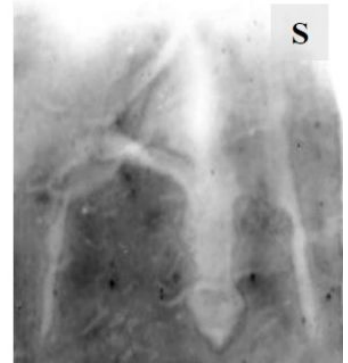

Figure 5. Photograph of rice root after planting in the blank soil (C) and the soil treated with $100 \mathrm{mg} \mathrm{kg}^{-1}$ Sulphur (S) (top). High resolution 2D profiles of $\mathrm{Sb}^{\mathrm{III}}$ and dissolved sulfide in the rhizosphere of rice obtained by MSBA-DGT (middle) and AgI-DGT (bottom) for 24-h deployments, respectively. $\mathrm{Sb}^{\mathrm{III}}$ and $\mathrm{S}^{-\mathrm{II}}$ is shown as DGT-measured metal fluxes, $f_{\text {DGT, }}\left(\mathrm{Sb}^{\mathrm{IIII}}: \mathrm{pg} \mathrm{cm}^{-2} \mathrm{~s}^{-1}\right.$ and $\left.\mathrm{S}^{-\mathrm{II}}: \mathrm{nmol} \mathrm{cm}^{-2} \mathrm{~s}^{-1}\right)$. 
For TOC art only

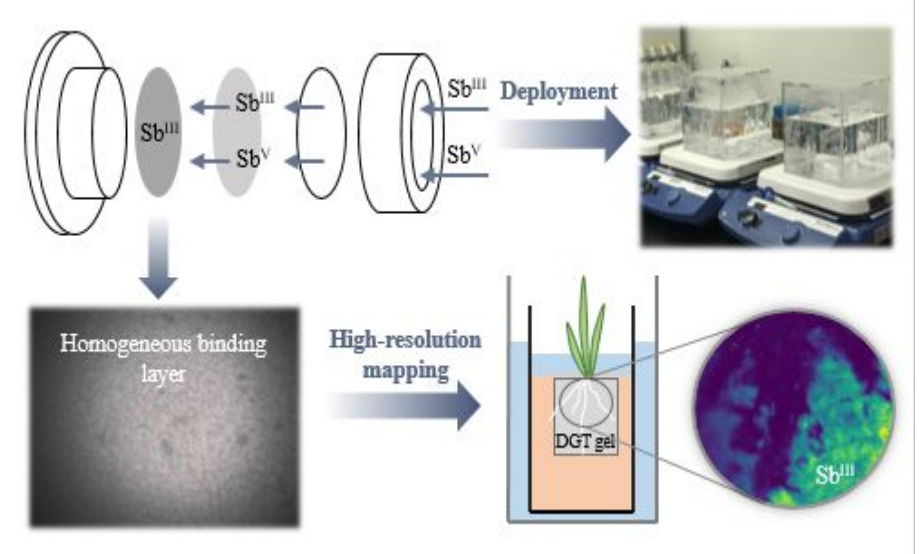

